原 著
||||||||||||||||||||||||||||||||||||

\title{
ランダムフォレスト法による 放射性廃棄物ドラム缶の分類
}

\author{
秦はるひ*,*,†, 石森 有* \\ *国立研究開発法人日本原子力研究開発機構バックエンド研究開発部門人形峠環境技術センター \\ 708-0698 岡山県苫田郡鏡野町上齋原 1550 \\ **岡山大学大学院自然科学研究科 \\ 700-8530 岡山県北区津島中 $3-1-1$ \\ †hata.haruhi@jaea.go.jp \\ 2016年7月 4日 受付 \\ 2016年9月 9日 受理
}

\begin{abstract}
放射性廃棄物ドラム缶の分類に対し，機械学習法の一つであるランダムフォレスト法が適用で きるか検討した。ウランの起源が天然または回収燃料かで分類された 954 点のドラム缶の $\gamma$ 線スペ クトルデータを利用した。300点を訓練データ用にとりわけ，残りの 654 点のスペクトルデータを 用いて, ランダムフォレストの分類の正答率を評価した。カウント数の対数の差分值をとる前処 理を行う場合, ランダムフォレスト法で 654 点を正確に分類できた。
\end{abstract}

Key Words: radioactive waste, machine learning, Random Forests, $\gamma$-ray measurement

\section{1. 序 論}

放射性廃棄物の処分では，設計への適合を 確認するため, 廃棄物中の放射性核種の種類や 量（インベントリ）を測定で明らかにする必要 がある。 $\gamma$ 線測定など, 廃棄物を外部から非破 壊測定することが合理的である。非破壞測定に よる確認が困難な放射性核種については, 廃棄 物から試料採取して化学処理するなど，破壊分 析を行う。

すべての廃棄物に対し破壊分析を行うこと は現実的でないため「スケーリングファクター 法（SF 法)」が確立された ${ }^{1,2)}$ 。SF 法では, 事 前にいくつかのグループに分類した廃棄物ごと の代表サンプルについて，化学分析と $\gamma$ 線測定 を行い，非破壊測定が困難な放射性核種と容易 な放射性核種の統計的な相関関係を求め, この 相関関係と $\gamma$ 線測定結果から化学分析を行って いない廃棄物の放射能インベントリを推定す る。
ウラン取扱施設から発生するウラン廃棄物に ついても, 天然起源のウラン (NU) と回収燃料 起源のウラン（RU）に分類できれば， SF 法で 必要なグルーピングがより確かなものとなり, 放射能インベントリの評価精度を向上できる。

筆者らは，内容物が確かなウラン廃棄物ド ラム缶の $\gamma$ 線スペクトルデータを訓練データと して，サポートベクターマシン（SVM）と呼 ばれる機械学習法を用い， ウラン廃棄物ドラム 缶の内容物や収納状況, 放出される $\gamma$ 線エネル ギーなどの事前情報を必要としない分類方法を 提案した ${ }^{3)}$ 。SVMは, 高次元空間にあるデー 夕と境界面の距離が最大となるような基準を 用いて，境界面を決定し分類する方法である。

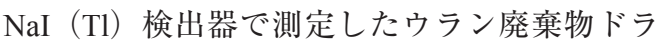
ム缶の $\gamma$ 線スペクトルデータ 12 点を訓練デー 夕として学習させ，955点のデータについて分 類を行ったところ，正答率が99\%を超える結 果となった。12点の訓練デー夕は, 運転切り 替えや年度が変わるときに出てくる最初のウラ 
ン廃棄物ドラム缶データから選んだ。

本研究では, 訓練データで各分類の特徵を 表す量（説明変数）を学習し，未知のデー夕を 分類・回帰するランダムフォレスト (RF) と 呼ばれるアルゴリズムを用いて， ウラン廃棄物 ドラム缶の $\gamma$ 線スペクトルデータによる分類を 試みる。RFは, 画像認識やビッグデータ解析 などでよく用いられる手法で, スペクトルデー 夕の分類では化学分析での利用例がある ${ }^{4-6) 。 ~}$

SVM 2クラス分類のためのアルゴリズム で，一度に多クラス分類はできないことから， 複数回繰り返して多クラス分類をすることにな る。一方，RFは一度に多クラス分類ができる ため, 実際の廃棄物の分類ではより優位な手法 となる可能性がある。

\section{2. 適用データ}

日本原子力研究開発機構人形峠環境技術セ
ンター製錬転換施設の廃水処理で発生した中 和澱物を封入したドラム缶 954 点（NU469点, RU485点）の $\gamma$ 線スペクトルデータを使用し た。既報3) で用いたデータと同一であるが, メンテナンス時等のデータを除いた。工程で使 用されたウランの起源によって NUまたはRU に分類している。

$\gamma$ 線測定は, 縦長の $130(\mathrm{~W}) \times 80(\mathrm{D}) \times 400$ (L) $\mathrm{mm}$ の $\mathrm{NaI}(\mathrm{Tl})$ 検出器 2 本, 鉄製の遮蔽 容器, ドラム缶の回転台から構成される $\mathrm{Q}^{2}$ 装 置（CANBERRA社製）で行った。この装置 で取得した $\gamma$ 線スペクトルの典型例を Fig. 1 に 示す。解像度は低いものの, 両方のスペクト ルに ${ }^{234 \mathrm{~m}} \mathrm{~Pa}$ 由来の $1001 \mathrm{keV}, 766 \mathrm{keV}$ と ${ }^{235} \mathrm{U}$ 由来 の $186 \mathrm{keV}, \mathrm{RU}$ のスペクトルでは, 原子炉内で 生成される ${ }^{232} \mathrm{U},{ }^{236} \mathrm{U}$ の子孫核種であるトリウ ム系列の ${ }^{212} \mathrm{~Pb}$ と ${ }^{208} \mathrm{Tl}$ 由来の $238 \mathrm{keV}, 510 \mathrm{keV}$, $583 \mathrm{keV}$ のピークが見られる（1チャネル＝約
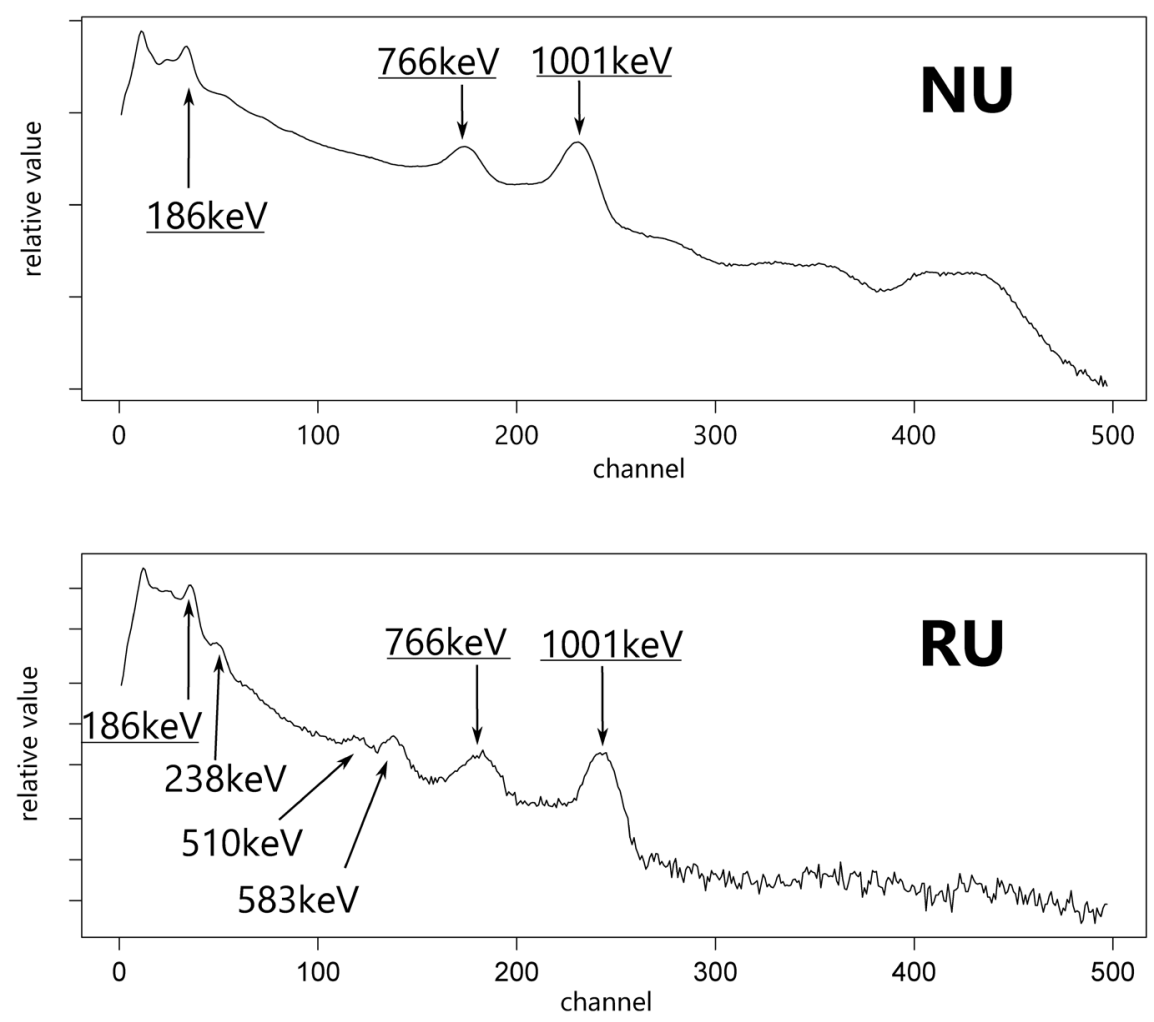

Fig. 1 Typical spectra of NU and RU with $\mathrm{Q}^{2}$ system. 
$4 \mathrm{keV})$ 。本研究では, スペクトルデータについ て，495チャネルまでに限定した。

\section{3. 解析手順}

Breiman $^{7)}$ が提案したRFは，与えた訓練デー タセットからランダムにサンプリングしたデー 夕で多数の訓練データセットを再構成し, 学習 により探知した分岐条件で，樹木状の分類モデ ル（決定木）を複数作成して分類するアンサン ブル学習アルゴリズムである。アンサンブル学 習とは，単独では精度が低い分類モデルを複数 組み合わせることによって精度を上げる学習法 である。RFでは，単独では分類精度が低い決 定木の分類予測を多数行い, それらの多数決を とることによって，分類精度を高める。

\section{$3 \cdot 1$ データの前処理}

効果的な前処理方法を検討するため，次に 示す前処理方法の違う 6 種類のデータ $d_{1} \sim d_{6}$ を用意した。カウント数を規格化したデー夕 $\left(d_{1}\right)$, カウントの少ない領域でピークを強調す るため, カウントの対数をとって規格化した デー夕 $\left(d_{2}\right)$ ， スペクトルの変化を強調するた め一次微分としてカウントの差分をとって規 格化したデー夕 $\left(d_{3}\right)$, カウントの少ない領域 での変化をより強調するため, カウントの対数 をとって，さらに差分をとって規格化したデー 夕 $\left(d_{4}\right)$, さらに変化を強調するため二次微分 としてカウントの差分をとったデータのさらに 差分をとって規格化したデータ $\left(d_{5}\right)$, カウン トの少ない領域での変化をより強調するため, カウントの対数の二次微分として差分をとった データのさらに差分をとって規格化したデー夕 (d $\left.d_{6}\right)$ を比較した。

$d_{1}:$ カウント数を規格化したもの

$$
d_{1}=\left\{\frac{x_{i}}{\sum_{i=1}^{495} x_{i}}\right\}_{i=1}^{495}
$$

$d_{2}$ : カウント数の対数を規格化したもの

$$
d_{2}=\left\{\frac{\log x_{i}}{\sum_{i=1}^{495} \log x_{i}}\right\}_{i=1}^{495}
$$

$d_{3}$ : カウント数の差分を規格化したもの（一 次微分)

$$
d_{3}=\left\{\frac{x_{i+1}-x_{i}}{\sum_{i=1}^{494}\left(x_{i+1}-x_{i}\right)}\right\}_{i=1}^{494}
$$

$d_{4}$ : カウント数の対数の差分を規格化したも の (一次微分)

$$
d_{4}=\left\{\frac{\log x_{i+1}-\log x_{i}}{\sum_{i=1}^{494}\left(\log x_{i+1}-\log x_{i}\right)}\right\}_{i=1}^{494}
$$

$d_{5}$ : カウント数の一次微分の差分を規格化し たもの (二次微分)

$$
d_{5}=\left\{\frac{x_{i+2}-2 x_{i+1}-x_{i}}{\sum_{i=1}^{493}\left(x_{i+2}-2 x_{i+1}-x_{i}\right)}\right\}_{i=1}^{493}
$$

$d_{6}$ : カウント数の対数の一次微分の差分を規 格化したもの（二次微分）

$$
d_{6}=\left\{\frac{\log x_{i+2}-2 \log x_{i+1}-\log x_{i}}{\sum_{i=1}^{493}\left(\log x_{i+2}-2 \log x_{i+1}-\log x_{i}\right)}\right\}_{i=1}^{493}
$$

\section{$3 \cdot 2 \mathrm{RF}$ の手順}

サンプリングしたデータを元のデータセッ トに戻すことにより，毎回同じデータセットか らサンプリングを行うブートストラップ法 ${ }^{7,8)}$ を用いて，訓練データセット $S$ から重複を許 したサンプリングを行い， $B$ 点のデー夕を抽出 し，これを $T$ 回繰り返して，新たな訓練デー夕 セット $S_{1}, S_{2}, \ldots, S_{T}$ として再構成する。新たな 訓練データセットを使い, ルートノードと呼ば れる出発点からある条件を用いて分岐させる。 Fig. 2 に示した○は，ノード（分岐点）で，条 件によって下位のノードに振り分ける。この分 岐を繰り返し，ノードのデータが単一のクラス となれば，それを終端ノード( $\square)$ としてラベル 付けを行い，決定木を完成する。この決定木 


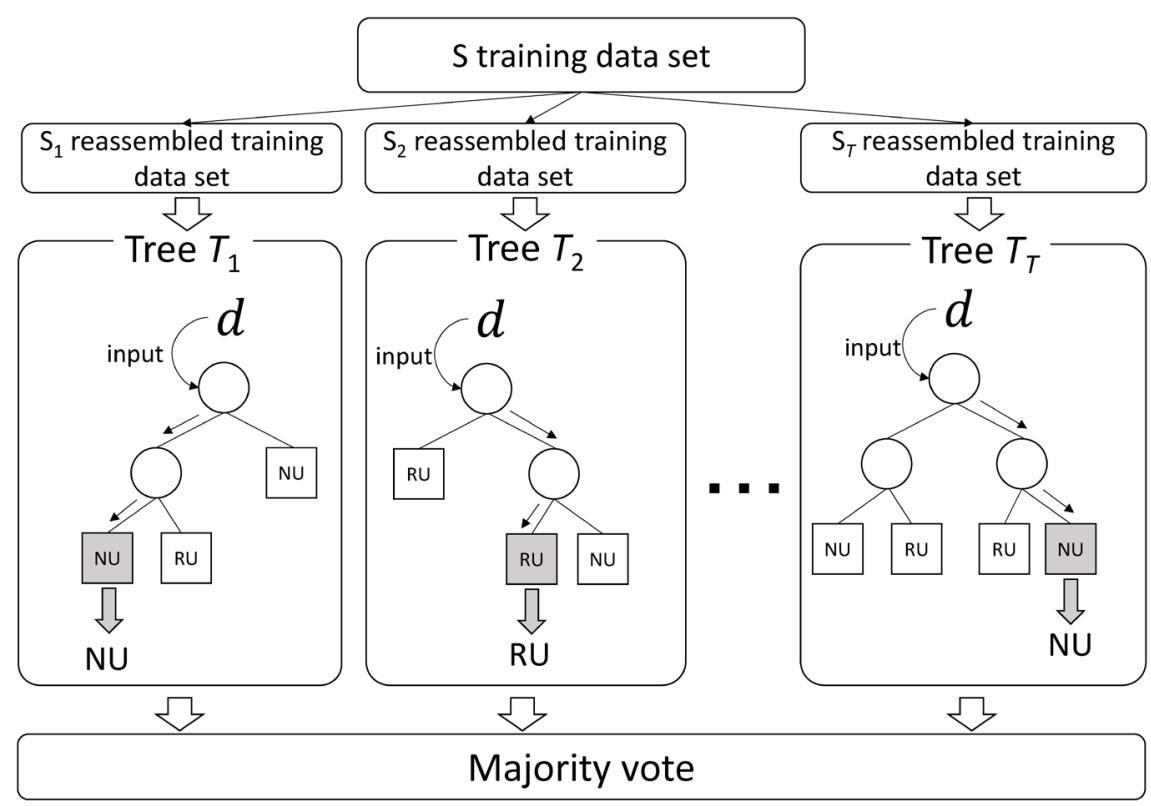

Fig. 2 Concept of RF classification to NU or RU.

に, 前処理したデータdを入力して, 辿り着い た終端ノードのラベルをその決定木の分類結果 とする。このようにして得られた $T$ 個の決定木 の分類結果の多数決により分類を確定する。単 独の決定木の具体的な作成手順を (1) (5)に示 す。

(1)ランダムに選んだ $m$ 個のチャネルについて, $B$ 点の訓練データの規格化したカウント数や 差分などを昇順に並び替える。隣り合う2つの 值の中央值をしきい值の候補とし, $(B-1) \times$ $m$ 個用意する (Fig. 3)。

(2)ジニ係数の減少度より, $(B-1) \times m$ 個のしき い値候補を評価する。

(3)最適なチャネルまたは相当する序数としきい 值の組を求め，分岐条件とする。

(4)あるノードに属する訓練デー夕と(3)で求めた 分岐条件のしきい值を比較して，左右の下位 のノードに分ける。分岐したノードについて も，それぞれ同様に分岐を繰り返す。

(5)ノードに属するデータのクラスがNUまたは RUのみになったら，そのノードを終端ノー ドとし，分岐を止める。終端ノードに行き着
いた訓練データのクラスをその終端ノードの 分類クラスとし，ラベルをつける。

(1)では, NUとRUの違いがカウント数やそ の差分に出ると考えられるため，NUとRUを 分類するしきい值の候補として，隣接する值の 中央值を用いている。

(2)，(3)で選定する最適なしきい值は，分岐 前の $t$ 番目のノード $t$ のジニ係数 $G I(t)$ から左右 の下位のノードへの分岐時のジニ係数 $G I\left(t_{\mathrm{Left}}\right)$ 及び $G I\left(t_{\text {Right }}\right)$ との差である減少度 $\Delta G I(t)$ が最 大となる序数としきい值の組み合わせであり， ジニ係数とその減少度は以下の式で導かれる。

$$
G I(t)=1-\sum_{C=\{\mathrm{NU}, \mathrm{RU}\}} p(C \mid t)^{2}
$$

$\Delta G I(t)=G I(t)-\left(p_{\text {Left }} G I\left(t_{\text {Left }}\right)+p_{\text {Right }} G I\left(t_{\text {Right }}\right)\right)$

$p_{\text {Left, }} p_{\text {Right }}$ は, あるノードに属するデー夕数に 対する，左または右の下位のノードに属する デー夕数の割合である。あるノード $t$ における クラス $C$ の事後確率 $p(C \mid t)$ は, そのノードに属 するデー夕数に対するクラス $C=\{\mathrm{NU}, \mathrm{RU}\}$ に属 するデー夕数の割合 $N_{C}(t) / N(t)$ で求められる。 


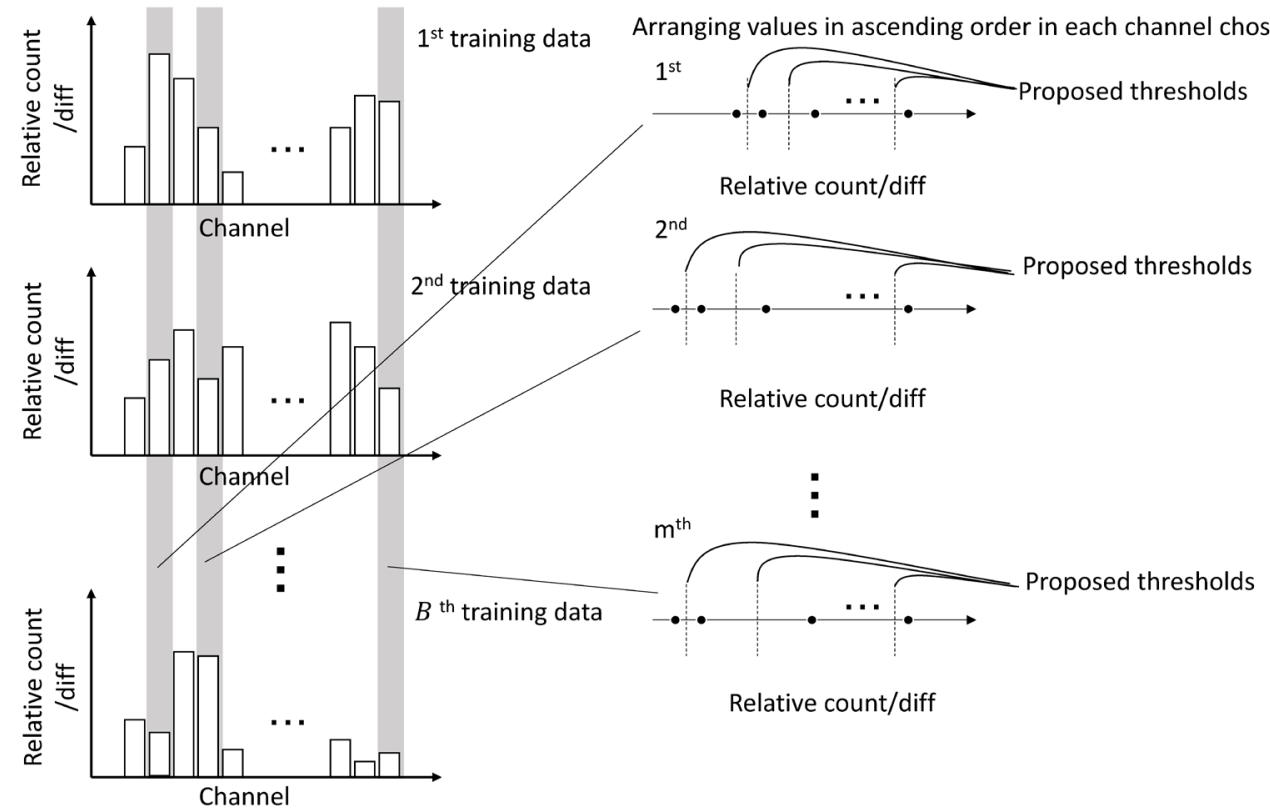

Fig. 3 Image of sampling from training data.

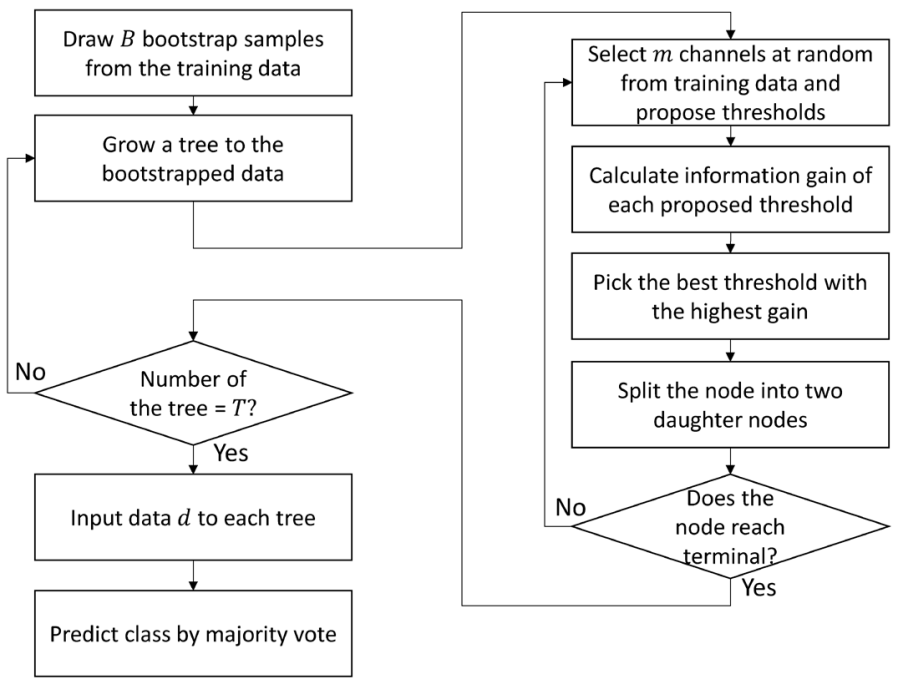

Fig. 4 Flow chart of RF algorithm.

ジニ係数が小さいほど, 分類結果に他クラ スの要素が少なく純度の高い状態を示し，1に 近づくほど他クラスの要素が多く混ざり合い不 純物が多い状態を示す。つまり，あるノードか ら下位のノードに分岐する際のジニ係数の減少 度が大きいほど，より精度よく分類ができる分
岐条件といえる。

分岐条件の探索では，事前に想定していな い特徵量が「潜在的な支配パラメー夕」として 抽出される可能性もあるため，事前のチャネル の絞り込みは行わない。全体のフローをFig. 4 に示した。 
本解析では, Windows 8.1 上で統計解析言語 $\mathrm{R}^{9)}$ にて行い, RFについてはRの randomForest パッケージ10)を使用した。

\section{$3 \cdot 3$ 検討の手順}

事前に全データ954点の $1 / 3$ 程度を目安に, NU, RUそれぞれ 150 点ずつ300点のデータを ランダムに選び, 残りの 654 点で分類精度を評 価した。300点は， $d_{1} \sim d_{6}$ の前処理をしたデー 夕にNUまたはRUのクラス情報を組み合わせ, 訓練データセット $S$ を作成するためのデータと した。残りの 654 点は, $d_{1} \sim d_{6}$ のデータの前処 理をして, RFの分類結果を実際のクラスと比 較して正答率を求めるためのデータとした。

本研究では, 訓練デー夕数によって, 分類 精度がどう変化するか前処理方法ごとに調べ た。このため訓練データセット $S$ とて事前に 準備した 300 点のデータから 2 300点（1～150 組）まで変化させた。それぞれ，50回ずつ， 訓練データセット $S$ をランダムに作成し，分類 を繰り返して，正答率を平均した。また，訓練 データセット $S$ から抽出するデー夕数 $B$ は, 訓 練データセット $S$ のデータ数と一致させ, 決定 木の個数 $T=500$ とし，ランダムに選ぶ説明変 数の数 $m$ は, すべての説明变数の個数の平方根 $\sqrt{495}, \sqrt{494}, \sqrt{493}$ より $m=22$ と設定した。

\section{4. 結果と考察}

6種の前処理方法による正答率を Fig. 5 に示 す。対数をとる方法 $\left(d_{2}\right)$ を除き，すべての方 法において, 平均の正答率は使用する訓練デー 夕数の増加に伴い収束している。 $d_{1}, d_{3}, d_{4}, d_{5}$ で は, $99 \%$ 以上の平均正答率となり，NUまたは RUへの分類に適用可能であることが確認でき た。特に, カウント数の対数の差分を 1 度とっ た方法 $\left(d_{4}\right)$ では, 訓練デー夕数が186点以上 で，正答率がすべて 1 となり，6種の前処理方 法の中で最適な前処理方法といえる。

300 点の訓練データを用いてRFを実行した ときのジニ係数の減少度の平均を相対度数 ${ }^{11)}$
でFig. 6に示す。差分を取らない $d_{1}$ と $d_{2}$ は, 400 チャネル以降（1600 keV相当）に減少度の 大きいチャネルがある。少ない訓練デー夕数で は他の方法に比べて正答率も低い。ウラン量が 少ないウラン廃棄物ドラム缶では, ウラン由来 の主要なピークが小さくなり, 相対的に, 440 チャネル付近の ${ }^{214} \mathrm{Bi}$ など, バックグラウンド 由来のピークが大きく見える。そのため， ウラ ン由来のピーク以外に 400 番目以降の説明変数 に減少度が大きいものが出現し, 正答率も低く なったと考えられる。 $d_{3}, d_{4}$ では，400番目以降 の説明変数の減少度の大きいものがなくなって おり，差分を取ることでバックグラウンドの影 響が抑えられることが解った。正答率が一番 高い $d_{4}$ では, 他の方法に比べ, $510 \mathrm{keV}, 583 \mathrm{keV}$ などの RUに特有のエネルギーピーク付近で減 少度が大きい説明変数がある。それにより，他 の方法より核種に応じた分類になり，正答率が 上がったと考えられる。

また, Fig. 6 における $d_{4}$ のジ二係数の減少度 の平均を見ると， 50 チャネル付近 $(200 \mathrm{keV}$ 相 当）より前のピークも重要であると認識してい ることがわかる。想定していたトリウム系列だ けでなく, 特性X線のピークも分類に使われて おり，事前に想定していなかった「潜在的な支 配パラメータ」が抽出されている。

\section{5. まとめ}

本研究ではウラン廃棄物ドラム缶の NUまた はRUへの分類について, $\mathrm{NaI} （ \mathrm{Tl})$ で計測し た $\gamma$ 線スペクトルに対する RFの適用可能性に ついて検討した。スペクトルデータに対する前 処理方法が異なる6種類のデータセットに対し てRFを実行し，最適な前処理方法を検討した。 その結果, カウント数を規格化する方法, カウ ント值の差分を規格化する方法，カウント值の 差分の差分を規格化する方法，カウント值の 対数の差分を規格化する方法の 4 種の方法で, 50 回試行の平均の正答率が $99 \%$ 以上に収束し, NUまたはRUへの分類が可能であることが確 
$\left(d_{1}\right)$

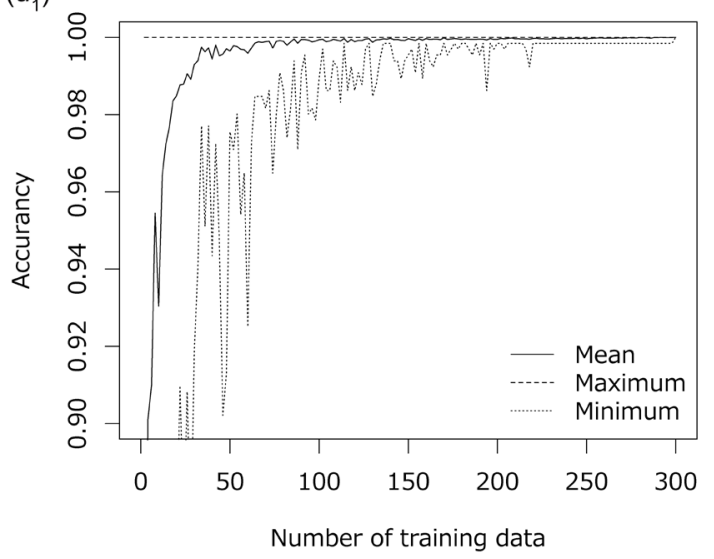

$\left(d_{2}\right)$

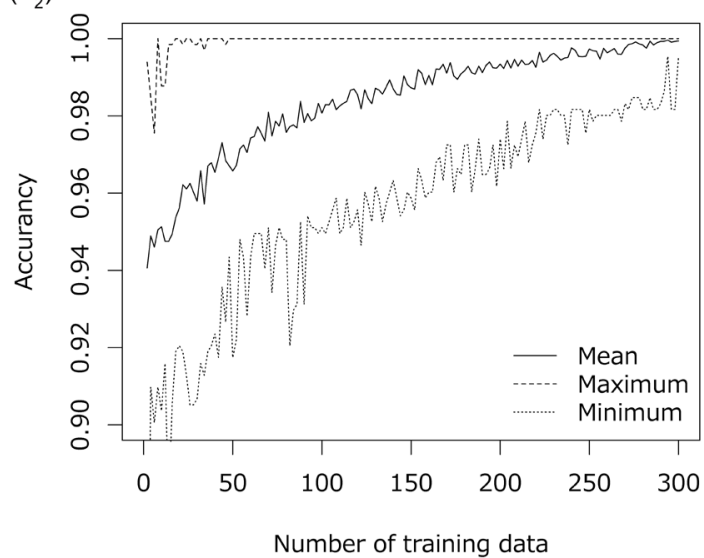

$\left(d_{3}\right)$

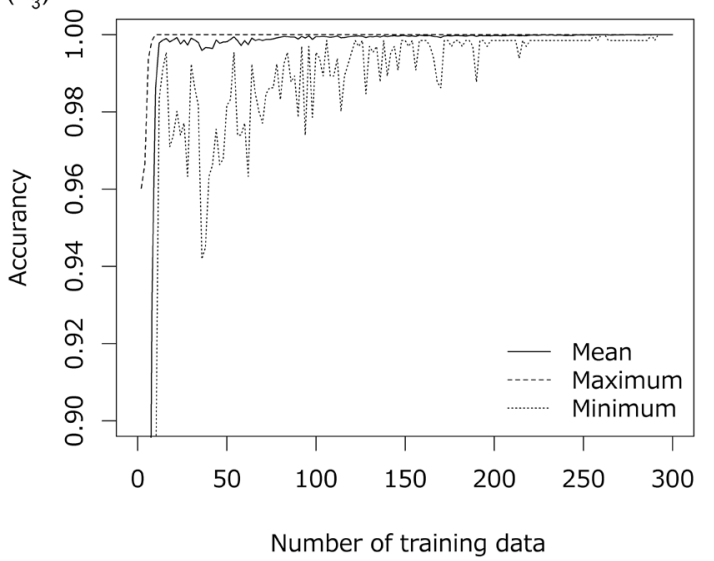

$\left(d_{4}\right)$

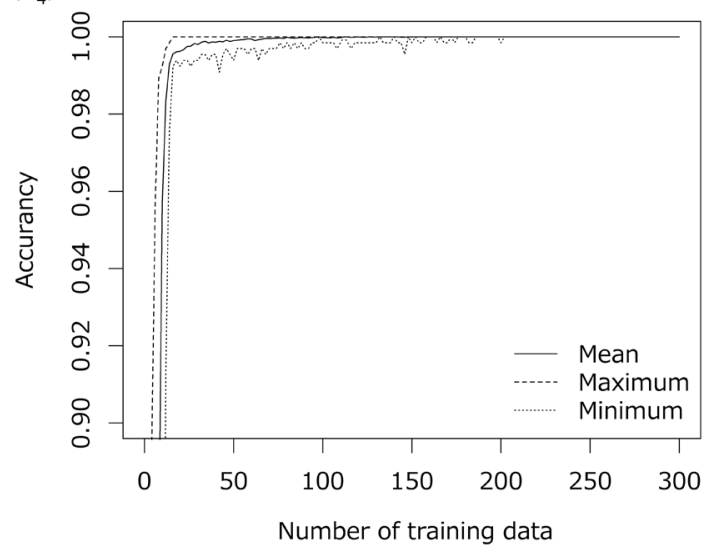

$\left(d_{5}\right)$

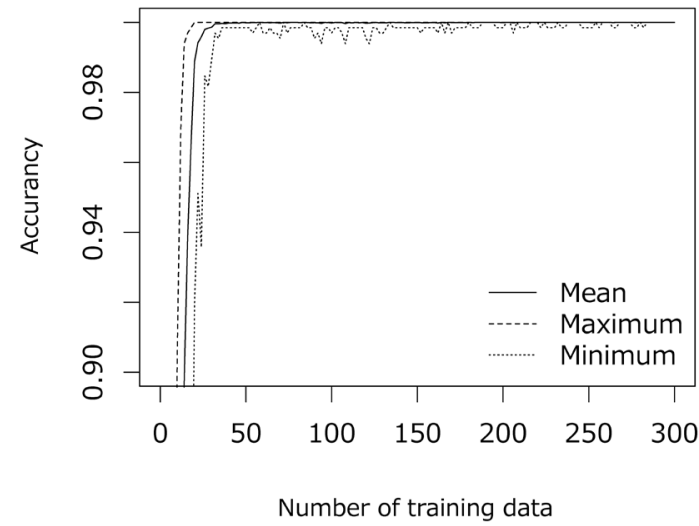

$\left(d_{6}\right)$

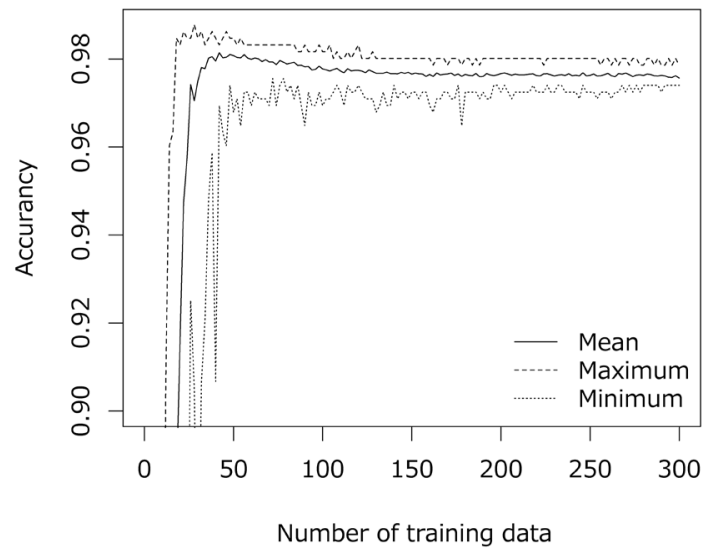

Fig. 5 Result of RF accuracy.

認できた。特に, カウント数の対数をとり，前 後の差分を取る前処理方法が一番高い正答率と なった。この方法では, 訓練デー夕数が 186 点
以上のとき，正答率はすべて 1 になり，6種の 前処理方法の中で最適な前処理方法と言える。

機械学習を用いた分類方法では, $\gamma$ 線スペク 
$\left(d_{1}\right)$

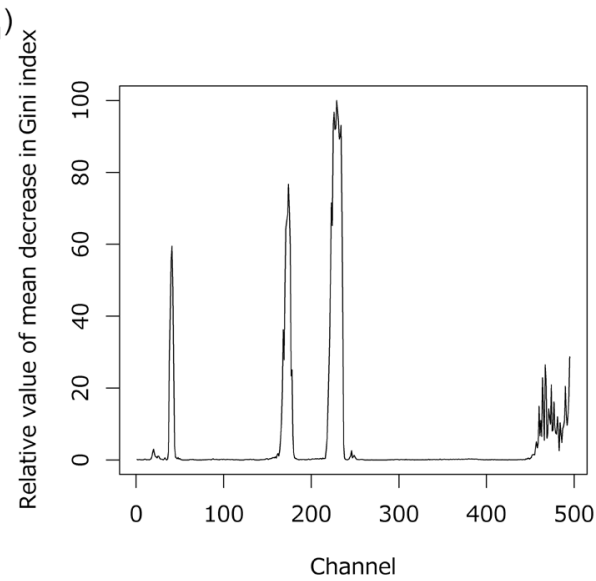

$\left(d_{2}\right)$

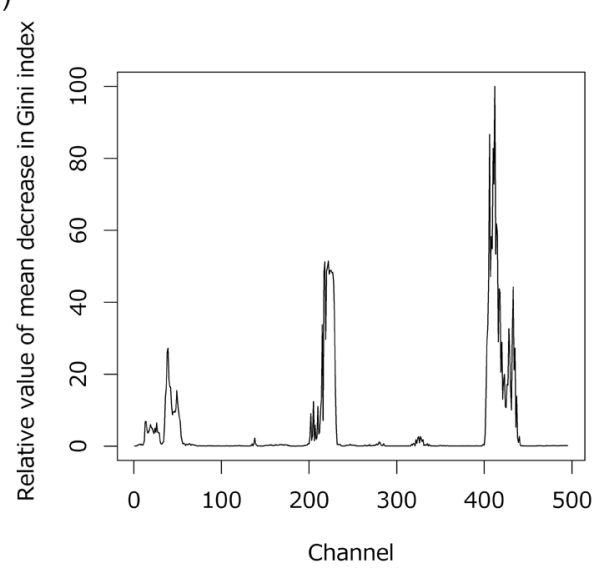

$\left(d_{3}\right)$

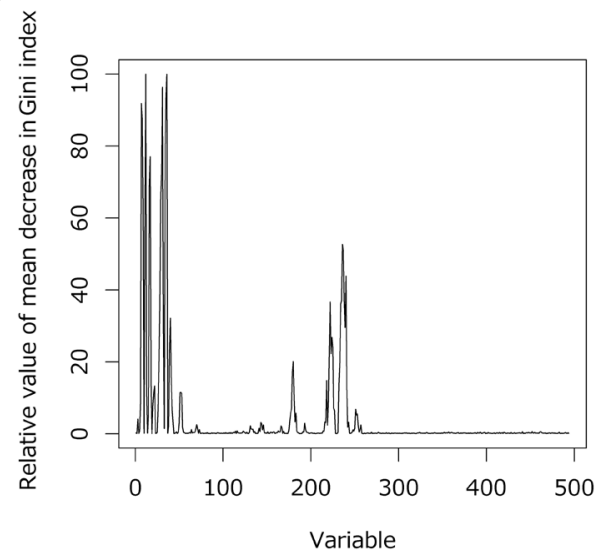

$\left(d_{4}\right)$

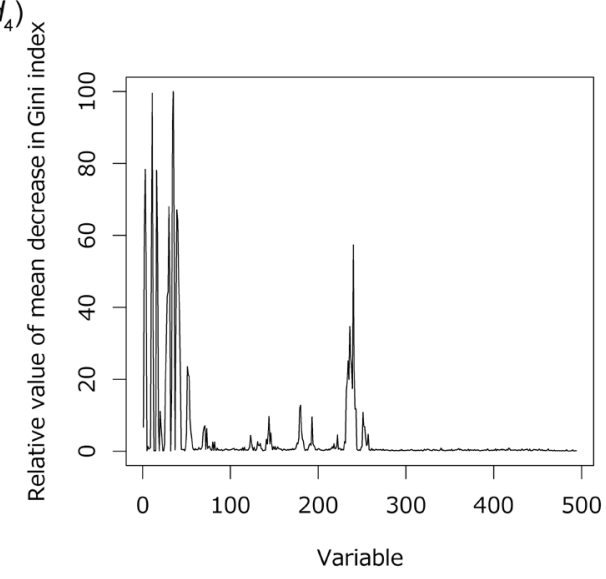

$\left(d_{5}\right)$

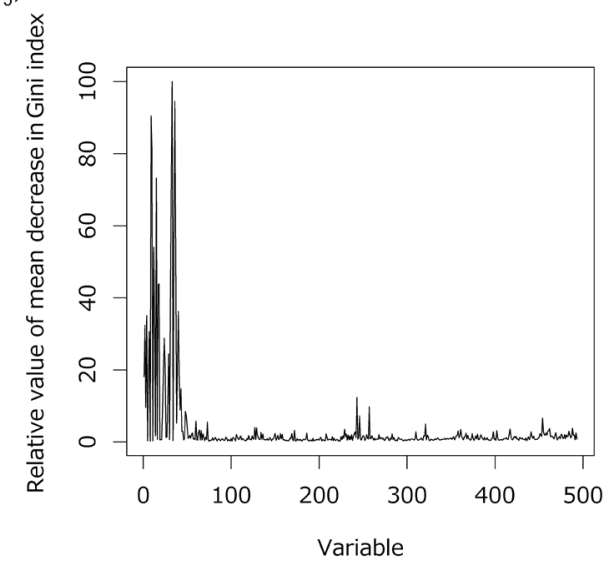

$\left(d_{6}\right)$

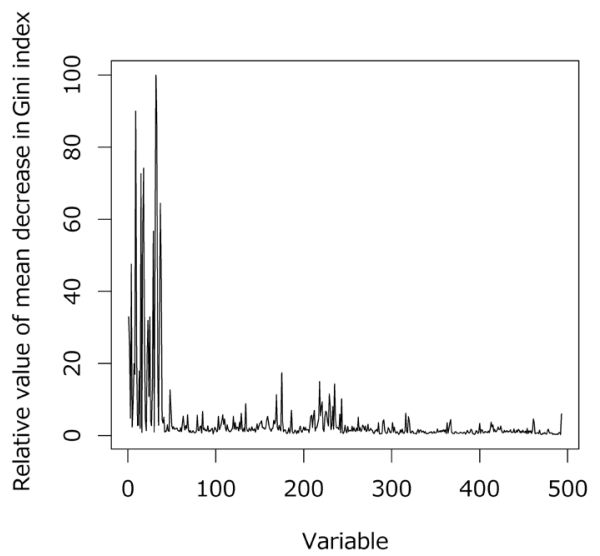

Fig. 6 Relative value of mean decrease in Gini index.

トルの各チャネルのカウント数のみを使用し, それ以外の内容物や収納状況, 放出される $\gamma$ 線 エネルギーなどの事前情報を必要としない。つ
まり，訓練データがあれば，内容物の遮蔽効 果を考慮する必要がなく, モデル化が難しい廃 裹物の分類に対しても，有効な手段だと考えら 
れる。また，識別結果を数值化できるため，特 に境界領域で，客観的な分類指標を提供でき， $\mathrm{SF}$ 法の補助ツールとして期待できる。

今後は，一度に多クラスへの分類ができる $\mathrm{RF}$ と 2 クラスへの分類のためのSVMを複数回 繰り返すことによって多クラス分類する方法と の比較を行い, 核原料や濃縮度の異なるウラン 等の多クラスへの拡張について検討する。ま た，原子炉廃棄物や核鑑識等への応用について も検討する。

\section{文献}

1) 日本原子力学会, 日本原子力学会標準ピット処 分及びトレンチ処分対象廃棄物の放射能濃度 決定に関する基本手順：2011, AESJ-SC-F022: 2011 (2012)

2) International Organization for Standardization, Nuclear energy — Nuclear fuel technology—Scaling factor method to determine the radioactivity of lowand intermediate-level radioactive waste packages generated at nuclear power plants, ISO 21238: 2007 (2007)

3) Hata, H., Yokoyama, K., Ishimori, Y., Ohara, Y., Tanaka, Y. and Sugitsue, N., Application of support vector machine to rapid classification of uranium waste drums using low-resolution $\gamma$-ray spectra,
Appl. Radiat. Isot., 104, 143-146 (2015)

4) Hilario, M., Kalousis, A., Pellegrini, C. and Müseller, M., Processing and classification of protein mass spectra, Mass Spectrom. Rev., 25, 409-449 (2006)

5) Satten, G. A., Datta, S., Moura, H., Woolfitt, A. R., Carvalho, M. da G., Carlone, G. M., De, B. K., Pavlopoulos, A. and Barr, J. R., Standardization and denoising algorithms for mass spectra to classify whole-organism bacterial specimens, Bioinformatics, 20, 3128-3136 (2004)

6) Menze, B. H., Petrich, W. and Hamprecht, F. A., Multivariate feature selection and hierarchical classification for infrared spectroscopy: Serum-based detection of bovine spongiform encephalopathy, Anal. Bioanal. Chem., 387, 1801-1807 (2007)

7) Breiman, L., Random forests, Mach. Learn., 45, 5-32 (2001)

8) Hastie, T., Tibshirani, R. and Friedman, J., The Elements of Statistical Learning: Data Mining, Inference, and Prediction, Second Edition, SpringerVerlag, New York (2009)

9) R Core Team, R: A language and environment for statistical computing. R Foundation for Statistical Computing, Vienna, Austria, October 2015, http:// www.R-project.org/

10) Liaw, A. and Wiener, M., Classification and regression by randomForest, $R$ News, 2, 18-22 (2002)

11) 下川敏雄, 杉本知之, 後藤昌司, Rで学ぶデー タサイエンス 9 : 樹木構造接近法, 共立出版, 東京 (2013) 


\title{
Abstract
}

\section{Classification of Radioactive Waste Drums Using Random Forests for Their $\mathrm{\gamma}$-ray Spectra}

\author{
Haruhi $\mathrm{HATA}^{*}, * *, \dagger$ and Yuu IsHIMORI ${ }^{*}$
}

*Ningyo-toge Environmental Engineering Center,

Sector of Decommissioning and Radioactive Waste Management, Japan Atomic Energy Agency

1550 Kamisaibara, Kagamino-cho, Tomata-gun, Okayama Pref. 708-0698, Japan

** Graduate School of Natural Science and Technology, Okayama University

3-1-1 Tsushima-naka, Kita-ku, Okayama Pref. 700-8530, Japan

The feasibility of Random Forests, one of machine learning methods was examined for the classification of radioactive waste drums. It was carried out using $954 \gamma$-ray spectra of drums which were already classified to natural or reprocessed uranium. After 300 spectra were selected at random to reassemble training datasets, the percentages of correct classification by Random Forests were evaluated with another 654 spectra. When the counts of spectra were reprocessed as the difference of their logarithm, Random Forests accurately classified 654 drums.

(Received July 4, 2016)

(Accepted September 9, 2016) 